\title{
Article \\ Effect of Current on Corrosion Resistance of Duplex Stainless Steel Layer Obtained by Plasma Arc Cladding
}

\author{
Juan Pu ${ }^{1, *(\mathbb{D})}$, Peng Xie ${ }^{1}$, Weimin Long ${ }^{2}$, Mingfang $\mathrm{Wu}^{1}{ }^{1}$, Yongwang Sheng ${ }^{3}$ and Jie Sheng ${ }^{3}$ \\ 1 School of Materials Science and Engineering, Jiangsu University of Science and Technology, \\ Zhenjiang 212003, China; 15160709894@163.com (P.X.); wu_mingfang@163.com (M.W.) \\ 2 Zhengzhou Research Institute of Mechanical Engineering, Zhengzhou 450001, China; brazelong@163.com \\ 3 Zhejiang Yongwang Welding Material Manufacturing Co, Ltd., Jinhua 321000, China; \\ papervip@163.com (Y.S.); s_jkd9078@163.com (J.S.) \\ * Correspondence: pu_juan84@163.com; Tel.: +86-15952815816
}

Citation: Pu, J.; Xie, P.; Long, W.; Wu, M.; Sheng, Y.; Sheng, J. Effect of Current on Corrosion Resistance of Duplex Stainless Steel Layer Obtained by Plasma Arc Cladding. Crystals 2022, 12, 341. https:// doi.org/10.3390/cryst12030341

Academic Editors: Yang Zhang and Yuqiang Chen

Received: 9 February 2022 Accepted: 25 February 2022 Published: 2 March 2022

Publisher's Note: MDPI stays neutral with regard to jurisdictional claims in published maps and institutional affiliations.

Copyright: (C) 2022 by the authors. Licensee MDPI, Basel, Switzerland. This article is an open access article distributed under the terms and conditions of the Creative Commons Attribution (CC BY) license (https:// creativecommons.org/licenses/by/ $4.0 /)$.

\begin{abstract}
In order to repair or strengthen stainless steel structural parts, the experiment was conducted by using plasma arc cladding technology to prepare 2205 duplex stainless steel (DSS) layers on the surface of Q345 steel. Their macro morphology and microstructure were observed by an optical microscope and the phase composition of microstructure was analyzed by an X-ray diffractometer instrument (XRD). The electrochemical behavior of 2205 DSS cladding layer under different current in $3.5 \% \mathrm{NaCl}$ etching solution was studied by the potentiodynamic polarization, the electrochemical impedance spectroscopy (EIS) and X-ray photoelectron spectrometer (XPS). The results showed that when the current was $100 \mathrm{~A}$, the forming of cladding layer was continuous, complete and fine with the dilution ratio of $11.43 \%$. The mass ratio of austenite to ferrite in the microstructure increased with the increase of current and it was up to the optimum of 1.207 with the current of $100 \mathrm{~A}$. Under such conditions, the self-corrosion potential of the cladding layer was up to the maximum while its corrosion current density reached the minimum, thus the corrosion resistance of the cladding layer reached the optimum. It was attributed to the existence of a large amount of $\mathrm{Cr}^{3+}$ and $\mathrm{Mo}^{6+}$ in the passive film of cladding layer, which can stabilize the passive film and promote the formation of $\mathrm{Cr}_{2} \mathrm{O}_{3}$ in the passive film.
\end{abstract}

Keywords: current; plasma arc cladding technology; 2205 duplex stainless steel; potentiodynamic polarization curve; passive film composition

\section{Introduction}

2205 duplex stainless steel (DSS) has good plastic toughness and weldability of austenitic steel and high strength and good corrosion resistance of ferritic steel [1]. Therefore, it is widely used in the cooling water heat exchangers, large oil storage tanks, the third-generation nuclear power fuel pool and seawater desalination systems in China [2-4]. During service, stainless steel structural parts (i.e. stainless steel-clad plate, using Q345 or $16 \mathrm{Mn}$ as the base metal and the stainless steel as the cladding material) are often damaged in the form of wear and corrosion [5,6], so it is important for parts to be repaired and strengthened. Surface remanufacturing technology is a means of using a heat source to clad(surface) alloy powder or wire on the surface of a workpiece to modify the properties of materials, such as wear resistance, corrosion resistance and oxidation resistance of coating (surfacing layer) [7-9]. It is beneficial to prolong the service life of large stainless steel structural parts, save precious and rare metal materials, finally reduce costs and improve benefits, which accords with the strategic policy of developing recycle economy and realizing sustainable development in China.

At present, the researchers mainly use the technology of laser cladding, CMT (Cold Metal Transfer Cladding) and TIG (Tungsten Inert Gas Arc Cladding) to prepare 2205 DSS cladding layer. Jing Ming et al. [10,11] successfully prepared 2205 DSS/TiC layer on 16Mn 
substrate with the help of laser cladding technology. The addition of TiC particles improved the hardness and wear resistance of duplex stainless-steel coating, but the layer started to crack when the mass fraction of $\mathrm{TiC}$ reached $15 \%$. Liu Shao et al. [12] studied the optimal process parameter of 2205 DSS prepared by CMT cladding with double wires. The optimal parameter was MAG (Metal Active Gas Arc Cladding) current 220 290 A of front wire and CMT + P current 160 240 A of rear wire. The cladding layer was composed of $40 \sim 60 \%$ austenite, which met the service requirements. Liu Yu et al. [13] prepared 2205 DSS surfacing layer by TIG using ER2209 as surfacing materials and studied the effect of sensitization treatment time on pitting corrosion resistance of surfacing layer. He believes that with the increase of sensitization treatment time, the pitting corrosion resistance of surfacing layer decreases. However, when the sensitization time exceeds $15 \mathrm{~min}$, the ferrite phase $\alpha$ occurs eutectoid reaction and $\sigma+\gamma_{2}$ forms. The formation of $\sigma$ decreases the pitting corrosion resistance of the surfacing layer. The literature [14-16] showed that the corrosion resistance will be deteriorated if the austenite phase and ferrite phase was imbalance in the microstructure of 2205 DSS cladding layer. In summary, the above research showed that optimizing the process parameters of surfacing technology to possess the optimal microstructure was the critical factor to obtain best comprehensive performance for DSS cladding layer. Additionally, how to improve the corrosion resistance of DSS cladding layer in various environments (such as atmospheric, salt solution, acid and so on) was also the key point to prolong its service life.

Plasma arc cladding technology as a high-energy beam surface cladding technology and a metal surface treatment technology, is one of the latest technologies developed after surfacing technology and laser cladding technology. It uses a high-temperature plasma arc to melt the alloy powder or wire and base metal. Then, with the transfer of plasma arc, the molten metal solidifies rapidly to form a metallurgical bonding layer. This technology has the advantages of low dilution rate, dense microstructure, small heataffected zone and good combination between surfacing layer and substrate. Compared with the laser cladding layer, the plasma arc cladding layer is not easy to produce defects such as pores, microstructure segregation and cracks [17-19]. So far, there are few reports on the preparation of 2205 duplex stainless steel layer by plasma arc cladding technology. In this paper, 2205 DSS layer will be prepared on the surface of Q345 steel by plasma arc cladding technology. The effects of different current on the macro morphology, austenite/ferrite mass ratio and corrosion resistance of the cladding layer will be studied. The corrosion resistance mechanism of the cladding layer will be revealed. The optimal process parameter of preparing 2205 DSS layer by plasma arc cladding will be acquired, which will guide the application of 2205 DSS cladding layer in engineering practice.

\section{Materials and Methods}

\subsection{Materials}

ER2209 stainless steel wire with a diameter of $1.2 \mathrm{~mm}$ was selected as the cladding wire, which was prepared by Jiangsu Jiuzhou New Material Technology Co., Ltd. A Q345 low alloy steel plate purchased on the market with the size of $160 \mathrm{~mm} \times 70 \mathrm{~mm} \times 10 \mathrm{~mm}$ was used as the base metal. Their chemical composition was listed in Table 1. 2205 DSS cladding layer was prepared on the surface of Q345 steel using 99.99\% argon as the shielding gas.

Table 1. Chemical compositions of wire and base metal.

\begin{tabular}{cccccccccc}
\hline Materials & $\mathbf{C}$ & $\mathbf{S i}$ & $\mathbf{M n}$ & $\mathbf{P}$ & $\mathbf{S}$ & $\mathbf{C r}$ & $\mathbf{N i}$ & $\mathbf{M o}$ & $\mathbf{F e}$ \\
\hline ER2209 & 0.02 & 0.53 & 1.90 & 0.02 & 0.004 & 21.73 & 9.12 & 2.67 & Balance \\
Q345 & $\leq 0.20$ & $\leq 0.50$ & $\leq 1.70$ & $\leq 0.035$ & $\leq 0.035$ & $\leq 0.30$ & $\leq 0.50$ & $\leq 0.10$ & Balance \\
\hline
\end{tabular}

\subsection{Preparation of 2205 DSS Cladding Layer}

2205 DSS cladding layer was prepared on the surface of Q235 steel by DML-V03AD plasma arc cladding equipment. The specific process parameters were wire feeding speed 
of $29 \mathrm{~mm} / \mathrm{s}$, welding speed of $6 \mathrm{~mm} / \mathrm{s}$, ion gas flow of $1 \mathrm{~L} / \mathrm{min}$, gas flow of $20 \mathrm{~L} / \mathrm{min}$ and Nozzle height of $10 \mathrm{~mm}$. The current was designed as $80 \mathrm{~A}, 90 \mathrm{~A}, 100 \mathrm{~A}, 110 \mathrm{~A}$ and 120 A to obtain the optimal parameters. The thickness of cladding layer was about $6 \mathrm{~mm}$. The sample of structure analysis was intercepted by wire cutting along the cross-section direction of the cladding layer. The sample of corrosion resistance analysis was cut along the direction perpendicular to the cross-section of the cladding layer.

\subsection{Macro Morphology and Microstructure Analysis}

The macro morphology of 2205 DSS cladding layer was observed by an Optical Microscope (OM, Oberkochen, Germany). It measured the melting width $W$, melting depth $\mathrm{H}$ and height $\mathrm{h}$ of the cladding layer. The dilution ratio was calculated according to the formula $\psi=\mathrm{H} /(\mathrm{H}+\mathrm{h})$. The schematic diagram was shown in Figure 1 . The metallographic specimens with the size of $25 \mathrm{~mm} \times 10 \mathrm{~mm}$ were taken along the cladding layer. After grinding and polishing, the sample was corroded for $10 \mathrm{~s}$ in Behara reagent. Behara reagent was composed of $88 \mathrm{ml} \mathrm{H}{ }_{2} \mathrm{O}+12 \mathrm{ml} \mathrm{HCl}+1.2 \mathrm{~g} \mathrm{~K}_{2} \mathrm{~S}_{2} \mathrm{O}_{5}$. The microstructure of cladding layer was observed by a ZEISS optical microscope (OM, Oberkochen, Germany) and a JSM-6480 scanning electron microscope (SEM, JEOL, Tokyo, Japan). The elements migration through the interface of the cladding layer and Q345 steel was tested by Energy Dispersive Spectrometer (EDS). The proportion calculation of austenite phase in the microstructure was obtained by Image Pro Analysis Software. The phase composition of cladding layer was analyzed by an X-ray diffractometer instrument (XRD-6000, Shimadzu, Kyoto, Japan) with $\mathrm{Cu}-\mathrm{K}_{\alpha}$ radiation and scanning angles $(2 \theta)$ between $10^{\circ}$ and $90^{\circ}$.

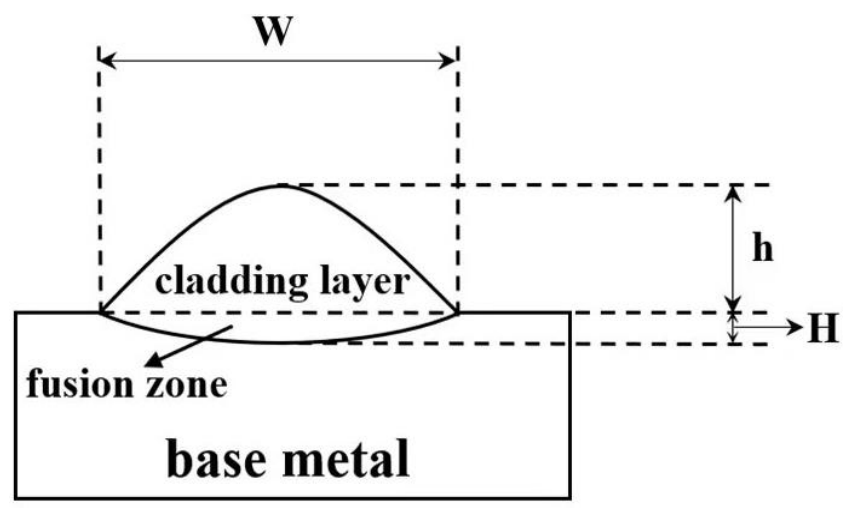

Figure 1. The schematic diagram of the dilution ratio calculation.

\subsection{Electrochemical Measurements}

The electrochemical measurements were carried out with the EGM283 Electrochemical Workstation with a three-electrode cell system, while the cladding layer acted as a working electrode, a saturated calomel electrode (SCE) as a reference electrode and a platinum plate as an auxiliary electrode. The specimens with dimensions of $10 \mathrm{~mm} \times 10 \mathrm{~mm} \times 5 \mathrm{~mm}$ for electrochemical tests, and the exposed measurement area was $10 \times 10 \mathrm{~mm}$ retained by the epoxy resin. Before the experiment, the samples were polished with silicon carbide (SiC) emery papers down to 2000\#, then ultrasonically cleaned in acetone and rinsed in distilled water. $3.5 \% \mathrm{NaCl}$ solution was taken as the etching solution.

The potentiodynamic polarization curves were recorded with a scanning rate of $1 \mathrm{mV} / \mathrm{s}$, starting from $-0.5 \mathrm{~V}$ to $1.5 \mathrm{~V}$. The electrochemical impedance spectroscopy (EIS) data were obtained with the frequency range from $100 \mathrm{kHz}$ to $10 \mathrm{mHz}$ and a sinusoidal potential perturbation of $5 \mathrm{mV}$ at the open-circuit potentials.

The experimental results were interpreted based on an equivalent electrical circuit. The capacitance measurements on the passive films were performed with a fixed frequency of $1 \mathrm{kHz}$, and the potential range from $1.0 \mathrm{~V}$ to $1.0 \mathrm{~V}$ (vs. SCE). All measurements were carried out at an ambient temperature of approximately 25 . 


\subsection{XPS Analysis}

In order to explore the corrosion mechanism of cladding layer under different currents, the chemical composition of passive film on the surface of the sample was tested. The samples were placed in the constant passivation potential of $0.3 \mathrm{~V}$ and polarized for $2 \mathrm{~h}$ to form a stable passive film on the surface of cladding layer. The chemical composition of the cladding layer passive films was investigated by X-ray photoelectron spectrometer (XPS) with a monochromatic $\mathrm{Al} \mathrm{Ka}$ radiation source and a hemispherical electron analyzer operated at the pass energy of $25 \mathrm{eV}$. The element composition and content were analyzed by comparing with the standard spectra of elements from XPS company's Perkin-Elmer data handbook and International Inc. XPS website. The fitting curve was performed with the commercial software of Avantage.

\section{Results and discussion}

\subsection{Effect of Current on Macro Morphology and Microstructure of Cladding Layers}

Dilution ratio and macro morphology are two important indexes to evaluate the formation quality of cladding layers [20]. Figure 2 shows the macro morphology of 2205 DSS cladding layer on the condition of different current. Figure 3 shows the corresponding dilution rate change curve of 2205 DSS cladding layer. When the current was $80 \mathrm{~A}$, melting amount of wire was not enough to produce a full and continuous cladding layer, and some pits appeared on the surface of cladding layer. As the current was $100 \mathrm{~A}$, a fine cladding layer formed. Its corresponding dilution ratio of cladding layer was $11.43 \%$. When the current was increased to $110 \mathrm{~A}$, the dilution ratio of cladding layer increased to $30.56 \%$. The dilution rate of the cladding layer determines the utilization rate of wire or powder and the quality of the cladding layer. On the premise of ensuring the perfect formation of the cladding layer and a good combination between the cladding layer and the substrate, the lower the dilution rate is, the higher the utilization rate of wire or powder and the higher the performance of the cladding layer is. If the dilution ratio is too small, the bonding performance of transition zone between the cladding layer and the substrate is poor. If the dilution ratio is too high, the alloy elements of base metal will deeply dilute the alloy composition of cladding layer, which will damage the performance of cladding layer [21-23].
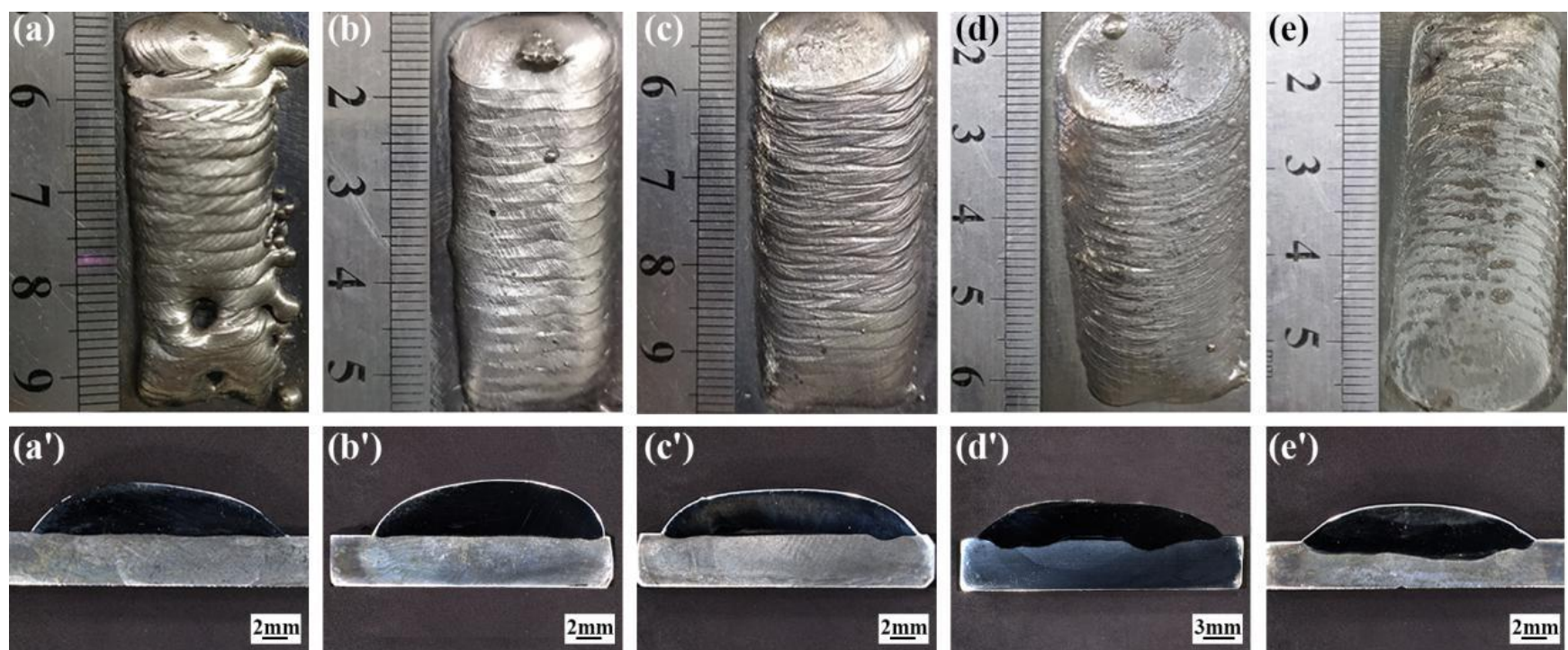

Figure 2. Macro morphology of 2205 DSS cladding layer under different current. $\left(\mathbf{a}, \mathbf{a}^{\prime}\right) 80 \mathrm{~A} ;\left(\mathbf{b}, \mathbf{b}^{\prime}\right)$ $90 \mathrm{~A} ;\left(\mathbf{c}, \mathbf{c}^{\prime}\right) 100 \mathrm{~A} ;\left(\mathbf{d}, \mathbf{d}^{\prime}\right) 110 \mathrm{~A} ;\left(\mathbf{e}, \mathbf{e}^{\prime}\right) 120 \mathrm{~A}$. 


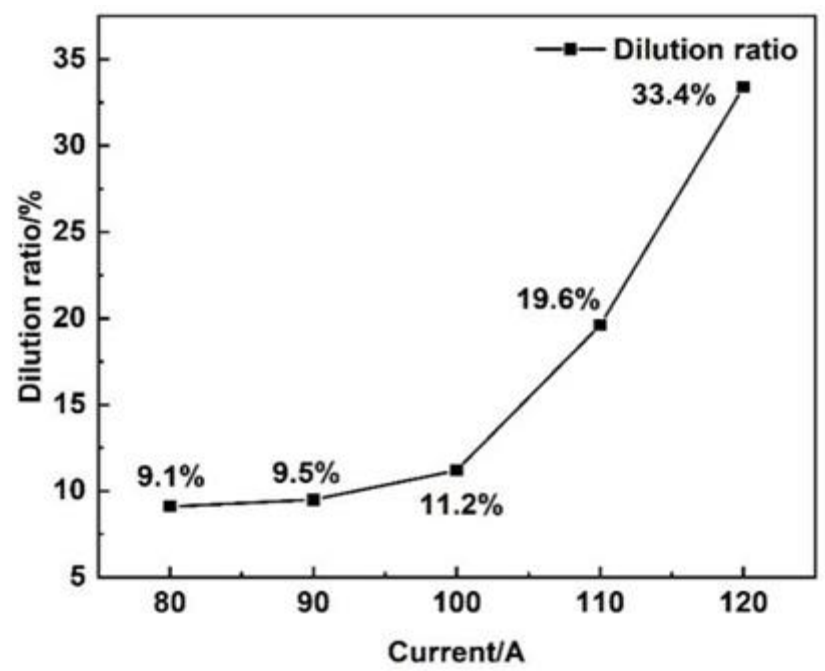

Figure 3. Variation curve on dilution ratio of 2205 DSS cladding layer under different current.

Figure 4 shows the SEM results of specimens under different current. The line scanning results show that the elements migration occur at the interface of the 2205 DSS cladding layer and the substrate, which suggests an excellent metallurgical combination between them. It can be seen from Figure $4 a-d$ that with the increase of the current, the grain size increased.
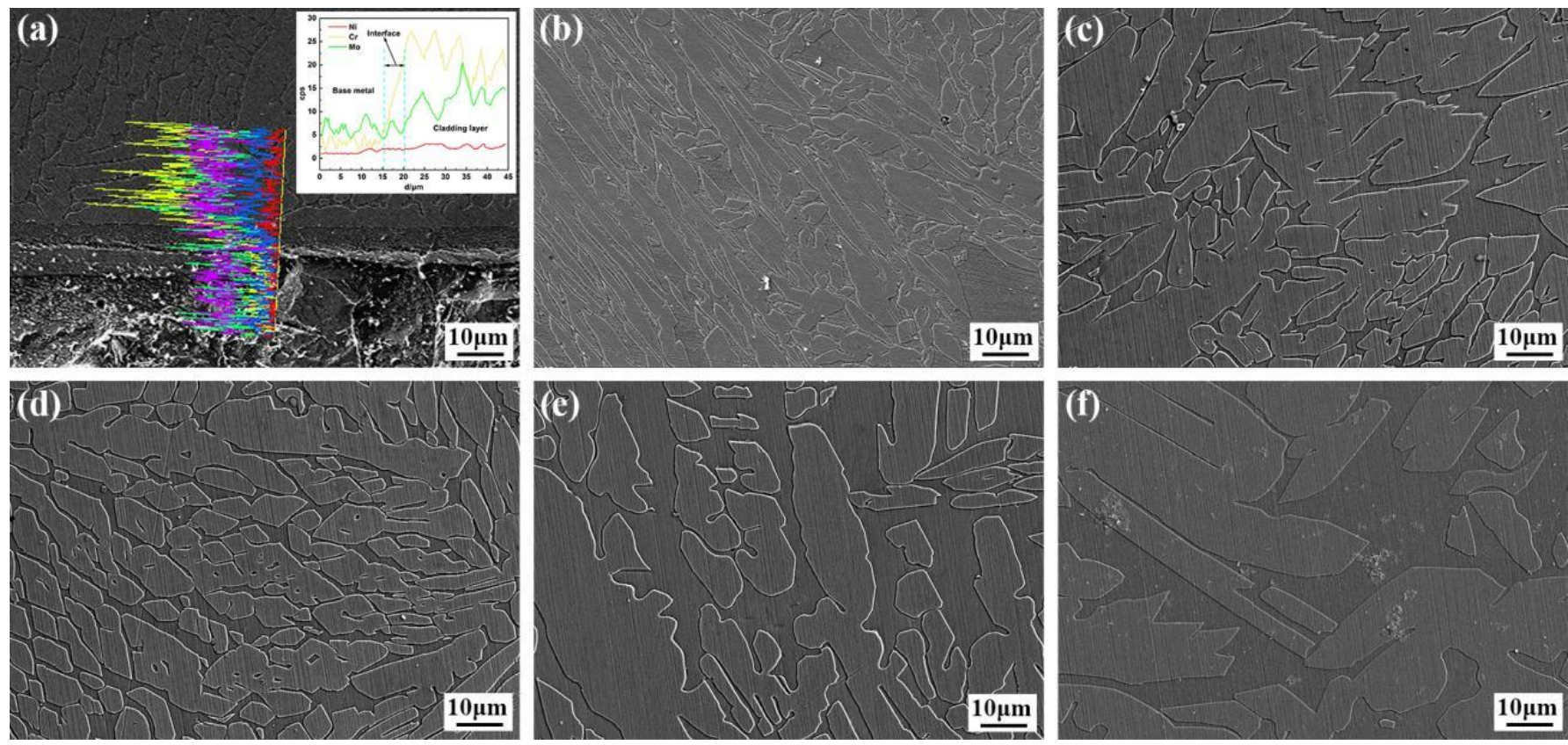

Figure 4. The SEM results of specimens under different current. (a) the Line Scanning result (80 A); (b) $80 \mathrm{~A}$; (c) $90 \mathrm{~A}$; (d) $100 \mathrm{~A}$; (e) $110 \mathrm{~A}$; (f) $120 \mathrm{~A}$.

In order to analyze the microstructural composition in details, the cross-sectional microstructure of the specimen and the top microstructure of the cladding layer on the condition of different current and austenite/ferrite mass ratio in mirostructure are shown in Figure 5. The austenite phase was shown as white while the gray region was the ferrite phase. 

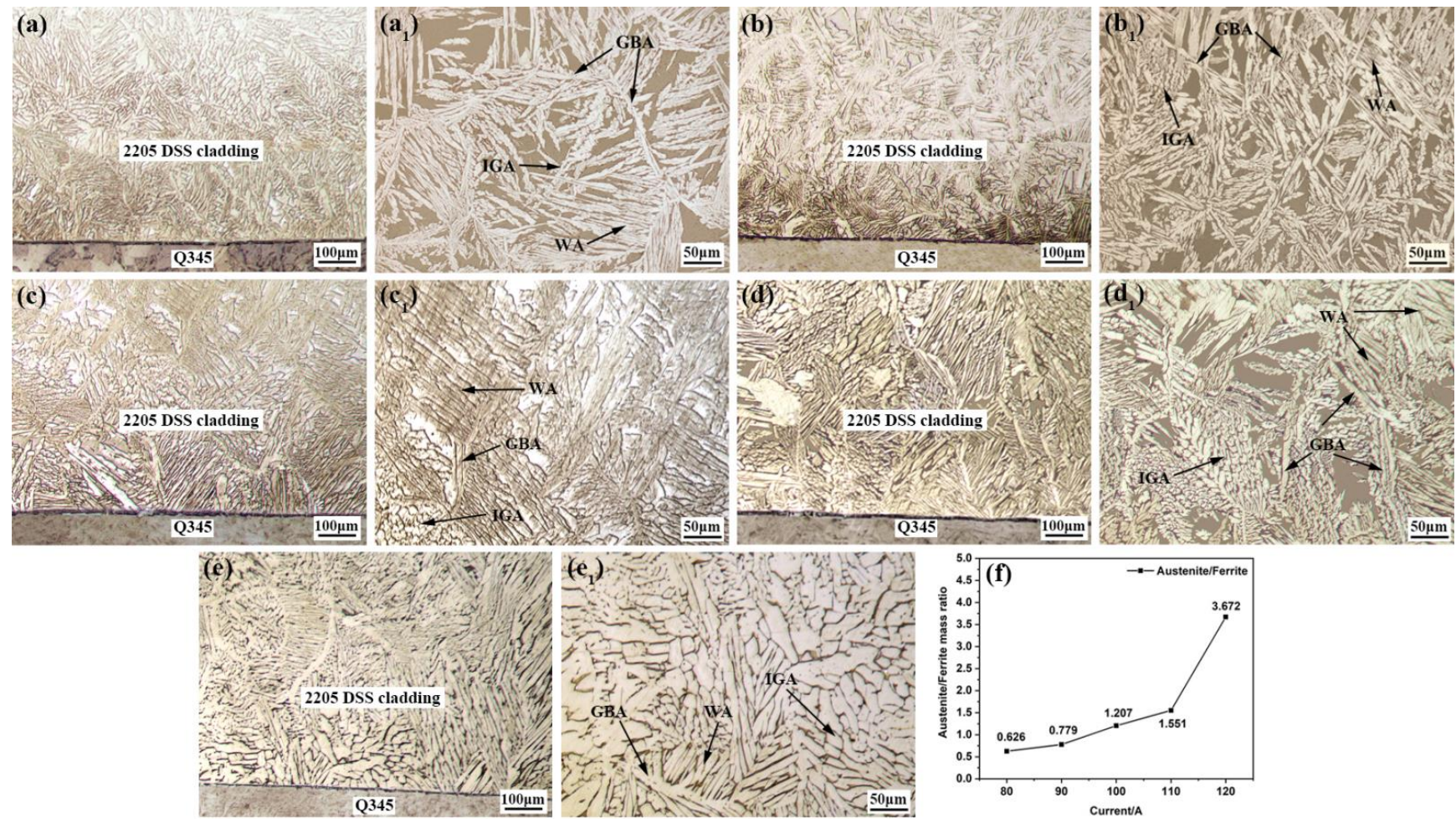

Figure 5. Microstructure of specimens under different current and Austenite/ Ferrite mass ratio. $\left(\mathbf{a}, \mathbf{a}_{\mathbf{1}}\right) 80 \mathrm{~A} ;\left(\mathbf{b}, \mathbf{b}_{\mathbf{1}}\right) 90 \mathrm{~A} ;\left(\mathbf{c}, \mathbf{c}_{\mathbf{1}}\right) 100 \mathrm{~A} ;\left(\mathbf{d}, \mathbf{d}_{\mathbf{1}}\right) 110 \mathrm{~A} ;\left(\mathbf{e}, \mathbf{e}_{\mathbf{1}}\right) 120 \mathrm{~A} ;(\mathbf{f})$ Austenite/ Ferrite mass ratio in mirostructure.

When the current was $80 \mathrm{~A}$ (see Figure $5 \mathrm{a}_{1} \mathrm{a}_{1}$ ), the austenite phase was composed of Grain-Boundary Austenite (GBA), Widmanstatten Austenite (WA) and Intragranular Austenite (IGA). The austenite phase and ferrite phase were relatively fine, with the average grain size of $63.50 \mu \mathrm{m}$ and $21.80 \mu \mathrm{m}$, respectively. The austenite/ferrite mass ratio in microstructure was 0.626 (see Figure $5 \mathrm{f}$ ). With the increase of current, the austenite/ ferrite mass ratio continued to grow and the grain size of austenite and ferrite increased. As the current was increased to $100 \mathrm{~A}$ (see Figure $5 c, c_{1}$ ), it can be observed that a large amount of IGA formed in the microstructure. The austenite/ferrite mass ratio was 1.207 (see Figure 5f). The average grain size of austenite was $79.25 \mu \mathrm{m}$ while that of ferrite was $44.81 \mu \mathrm{m}$. When the current was $110 \mathrm{~A}$ and $120 \mathrm{~A}$ (see Figure $5 \mathrm{~d}, \mathrm{~d}_{1}, \mathrm{e}, \mathrm{e}_{1}$ ), the austenite/ ferrite mass ratio were 1.551 and 3.672, respectively (see Figure $5 \mathrm{f}$ ). The average grain size of austenite were $98.52 \mu \mathrm{m}$ and $119.70 \mu \mathrm{m}$ while that of ferrite were $45.81 \mu \mathrm{m}$ and $51.60 \mu \mathrm{m}$.

In general, the structure solidification of 2205 DSS cladding layer is ferrite mode [14,15]. At the beginning of solidification, ferrite is entirely formed. While the temperature falls below the solid solution line, the ferrite starts to transfer to austenite. Since austenitizing stable elements (such as $\mathrm{C}, \mathrm{Mn}, \mathrm{Ni}$ and so on) are easily enriched in the grain boundary and sub-grain boundary of ferrite, GBA preferentially grows along the grain boundary of ferrite. After GBA completely covering the grain boundary of ferrite, WA begins to grow along the direction perpendicular to the grain boundary of ferrite. Meanwhile, IGA nucleates and grows up in the grains of ferrite. As can be seen from the above figures, with the increase of current, the heat input increases, it means the transformation time from ferrite into austenite increases, so the amount of austenite in microstructure increases. Moreover, the content of austenitizing stable elements (such as Mn and Ni) in ER2209 wire is increased, which promote the formation of austenite. The microstructure is gradually coarsened with the increase of the current. 
Figure 6 shows the XRD analysis results of 2205 DSS cladding layer with the current of 90-110 A. It also confirmed that the microstructure was mainly composed of the ferrite phase and the austenite phase.

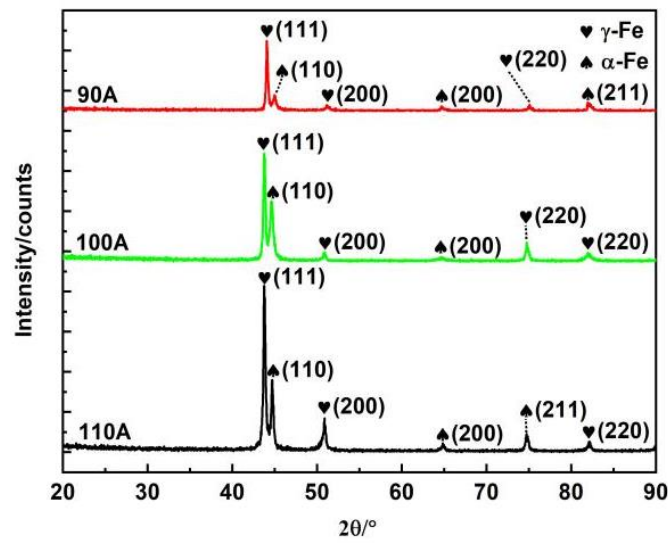

Figure 6. XRD results of 2205 DSS cladding layer under different current.

3.2. Analysis on Potentiodynamic Polarization Curve of 2205 DSS Cladding Layer under Different Current

In order to analyze the effect of current on the corrosion resistance of 2205 DSS cladding layer, an electrochemical corrosion test was carried out. The potentiodynamic polarization curves of cladding layer under different current are shown in Figure 7. On the condition of different current, the passive film formed in $3.5 \% \mathrm{NaCl}$ solution was very stable. The passive potential of cladding layer was in the potential region from -0.03 to $0.40 \mathrm{VSCE}$ (0.41 VSCE, $0.46 \mathrm{VSCE})$. At the initial stage of corrosion, the dissolution rate of passive film is close to its regeneration rate, so the passive film is in the equilibrium state of dissolution and regeneration [13]. With the increase of potential, the corrosion current increases and the dissolution rate of passive film increases. When the dissolution rate is greater than the regeneration rate, the passive film breaks down and the cladding layer is corroded.

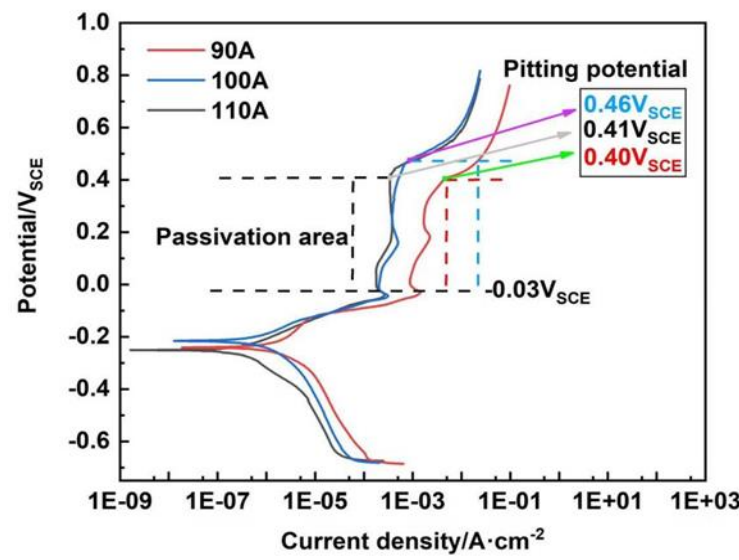

Figure 7. Potentiodynamic polarization curves of samples under different current.

The polarization curve was fitted by CView analysis software to obtain the selfcorrosion potential and corrosion current density. The fitting results are shown in Table 2. The relationship between current and self-corrosion potential was $100 \mathrm{~A}(-0.213 \mathrm{~V})>90 \mathrm{~A}$ $(-0.241 \mathrm{~V})>110 \mathrm{~A}(-0.251 \mathrm{~V})$, and the relationship between current and corrosion current density was $100 \mathrm{~A}\left(1.95 \times 10^{-7}\right)<110 \mathrm{~A}\left(3.69 \times 10^{-7}\right)<90 \mathrm{~A}\left(3.09 \times 10^{-6}\right)$. The selfcorrosion potential represents the difficulty of corrosion of the cladding layer. The greater the self-corrosion potential, the less likely corrosion will occur. The corrosion current density represents the actual corrosion rate of cladding layer. The smaller the corrosion 
current density is, the smaller the corrosion rate is [24]. Therefore, when the current was $100 \mathrm{~A}$, the self-corrosion potential of cladding layer was the maximum while the corrosion current density was the minimum, indicating that the corrosion resistance of cladding layer was optimal.

Table 2. Fitting parameters obtained by using CView analysis software to deal with the potentiodynamic polarization curves.

\begin{tabular}{ccc}
\hline Current & Potential// $\mathbf{S C E}$ & Current Density/A.cm $\mathbf{c}^{-2}$ \\
\hline 90 & -0.241 & $3.09 \times 10^{-6}$ \\
100 & -0.213 & $1.95 \times 10^{-7}$ \\
110 & -0.251 & $3.69 \times 10^{-7}$ \\
\hline
\end{tabular}

\subsection{Chemical Stability of Passive Film Formed on the Cladding Layer under Different Current}

In order to investigate the relative stability of passive films formed on the surface of 2205 DSS cladding layer under different current, the samples were in $3.5 \mathrm{wt} . \% \mathrm{NaCl}$ etching solution for passivated $1 \mathrm{~h}$ at $0.2 \mathrm{VSCE}$. Electrochemical impedance spectroscopy (EIS) measurements were carried out after passive film generation. Figure 8 displays the EIS results of three species passive film formed under the current of $90 \mathrm{~A}, 100 \mathrm{~A}$ and $110 \mathrm{~A}$. It can be observed that the three species passive films have similar impedance characteristics from the Nyquist plots (Figure 8a), and there is a capacitive arc with different radius in the test frequency range. These curves present the influence of different current on the impedance behavior of passive film. As previously reported in the literature [25-28], the polarization resistance of passive film is relevant to the diameter of the semicircular arc in impedance measurement. The increase of the semicircular arc means the enhancement of the passive film stability. The results demonstrated that the radius of capacitive arc of passive film with the current of $100 \mathrm{~A}$ reaches up to the maximum, which means that the corrosion resistance of passive film is optimal.
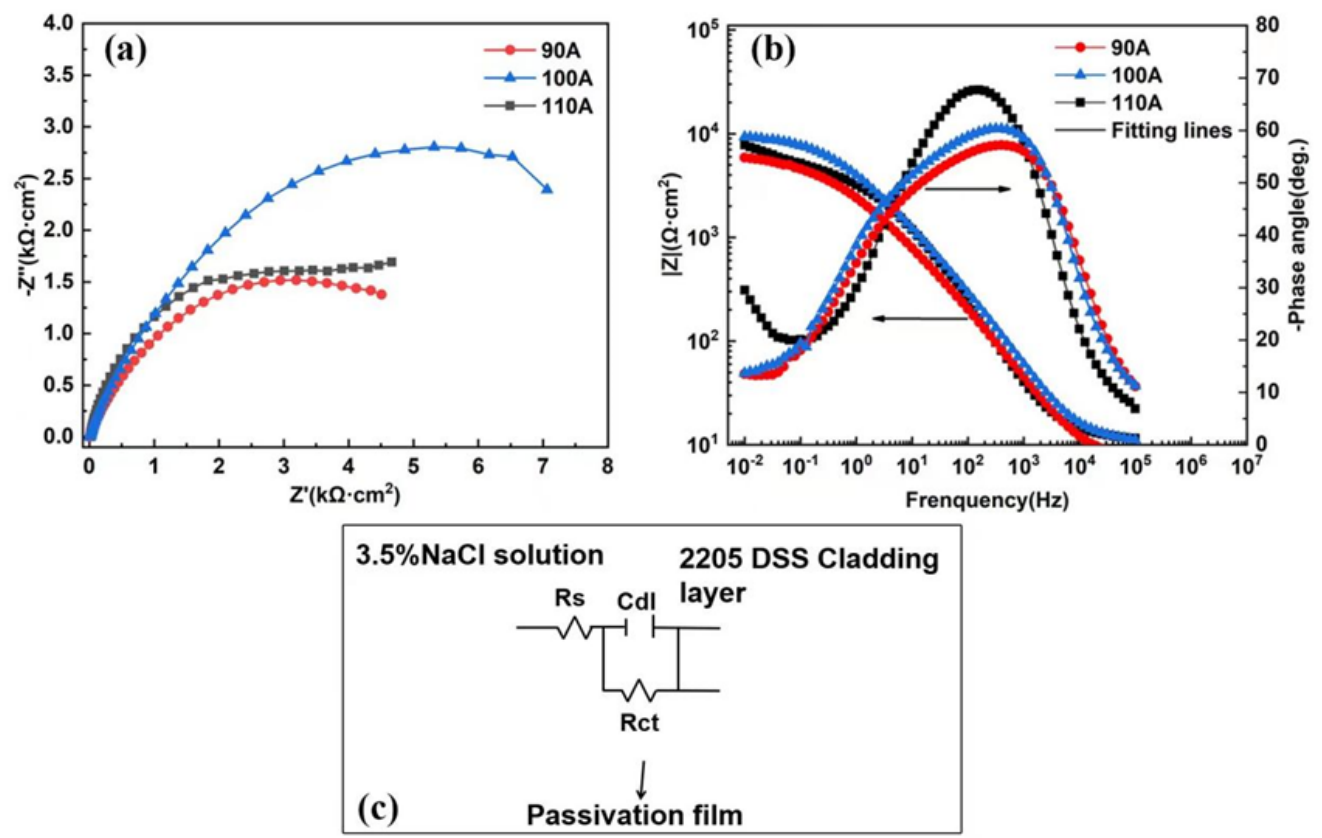

Figure 8. EIS date of passive film on the surface of 2205 DSS cladding layer under different current. (a) Nyquist plots; (b) Bode plots; (c) Equivalent circuit.

Figure $8 \mathrm{~b}$ shows the Bode plots of passive films under different current. Figure $8 \mathrm{c}$ presents the equivalent circuit which is used to fit the impedance data of passive film. In this model [13], $\mathbf{R}_{\mathbf{s}}$ represents the solution resistance, $\mathbf{R}_{\mathbf{c t}}$ is the charge transfer resistance 
of passive film and $\mathrm{C}_{\mathrm{dl}}$ is the corresponding double-layer capacitance. Table 3 lists the electrochemical fitting parameters based on the equivalent circuit displayed in Figure 8c. The dispersive exponent $\mathbf{n}$ means the deviation from the ideal capacitance, which always lies from 0.5 to 1 . As shown in Table 3, with the increase of current, the $\mathbf{R}_{\mathbf{c t}}$ value of passive film increased firstly and then decreased. It reached the maximum of $9078 \Omega \cdot \mathrm{cm}^{-2}$ with the current of $100 \mathrm{~A}$, which suggested that the compactness and stability of passive film was the optimum.

Table 3. Fitting parameters of EIS results obtained from a proposed equivalent model.

\begin{tabular}{ccccc}
\hline Current & Rs $\left(\boldsymbol{\Omega} \cdot \mathbf{c m}^{-\mathbf{2}}\right)$ & $\mathbf{C d l}\left(\mathbf{F} \cdot \mathbf{c m}^{-\mathbf{2}}\right)$ & $\operatorname{Rct}\left(\boldsymbol{\Omega} \cdot \mathbf{c m}^{-\mathbf{2}}\right)$ & $\mathbf{n}$ \\
\hline 90 & 10.3 & $3.50 \times 10^{-5}$ & 5443 & 0.84 \\
100 & 7.8 & $4.77 \times 10^{-5}$ & 9078 & 0.92 \\
110 & 4.7 & $8.12 \times 10^{-5}$ & 5203 & 0.81 \\
\hline
\end{tabular}

\subsection{XPS Results and Corrosion Mechanism of Cladding Layer}

The excellent corrosion resistance of 2205 duplex stainless steel is due to the spontaneous formation of a dense passive film on the surface in a corrosive environment. In order to explore the corrosion resistance mechanism of 2205 duplex stainless steel cladding layer under different current, XPS analysis was undertaken to provide more information on the chemical composition of the passive films, finally the optimal process parameters were obtained.

The results of XPS spectra obtained for the samples passivated at 0.3 VSCE in 3.5\% $\mathrm{NaCl}$ solution sputtered for $2 \mathrm{~h}$ are shown in Figure 9. The results indicated that the constitution of the three species passive film were similar even if the current was different. The observed spectra indicated the presence of $\mathrm{Cr}, \mathrm{Fe}, \mathrm{Mo}, \mathrm{Ni}, \mathrm{O}$ and $\mathrm{C}$ peaks. According to the peak strength, $\mathrm{Cr}, \mathrm{Fe}, \mathrm{Mo}$ and $\mathrm{Ni}$ dominate the components of the passive film. The peak intensity of the $C$ element signal was small, so the $C$ element may be an impurity element introduced in the preparation process.

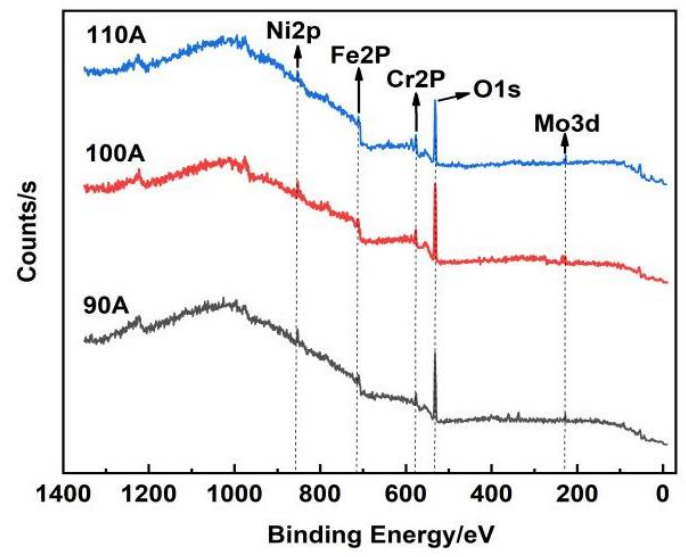

Figure 9. XPS spectra of passive film on the surface of 2205 DSS cladding layer after passivation for $2 \mathrm{~h}$ at $0.3 \mathrm{VSCE}$ in $3.5 \% \mathrm{NaCl}$ solutions.

Figures 10-14 present the Cr2p, Fe2p, Mo2p, Ni2p and O2p XPS spectra of three different passive films, respectively. It can be seen from Figure 10 that the signal of $\mathrm{Cr} 2 \mathrm{p}$ performed primary three peaks, which represented the metal $\mathrm{Cr}(574.3 \mathrm{eV}), \mathrm{Cr}_{2} \mathrm{O}_{3}$ $(576.4 \mathrm{eV})$ and $\mathrm{Cr}(\mathrm{OH})_{3}(577.3 \mathrm{eV})$. The composition proportion of $\mathrm{Cr}_{1} \mathrm{Cr}_{2} \mathrm{O}_{3}$ and $\mathrm{Cr}(\mathrm{OH})_{3}$ in the passive film of cladding layer was different on the condition of different currents. The content of $\mathrm{Cr}_{2} \mathrm{O}_{3}$ in the passive film increased firstly and then decreased with the increase of current. The content of $\mathrm{Cr}_{2} \mathrm{O}_{3}$ reached up to the maximum with the current of $100 \mathrm{~A}$. 

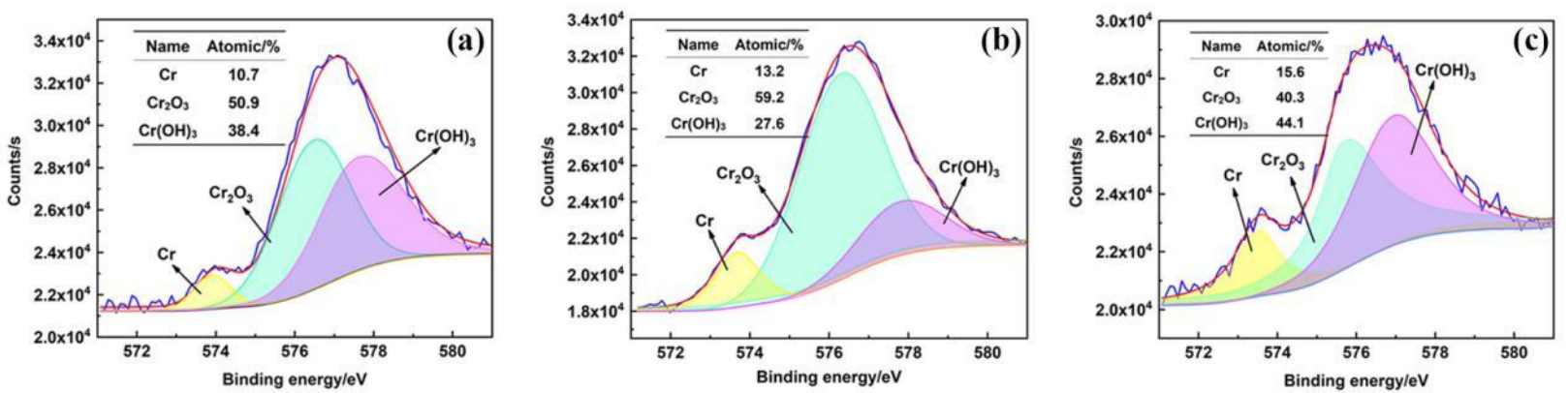

Figure 10. Cr2p peak fitting of 2205 DSS cladding layer under different current. (a) 90 A; (b) 100 A; (c) $110 \mathrm{~A}$.
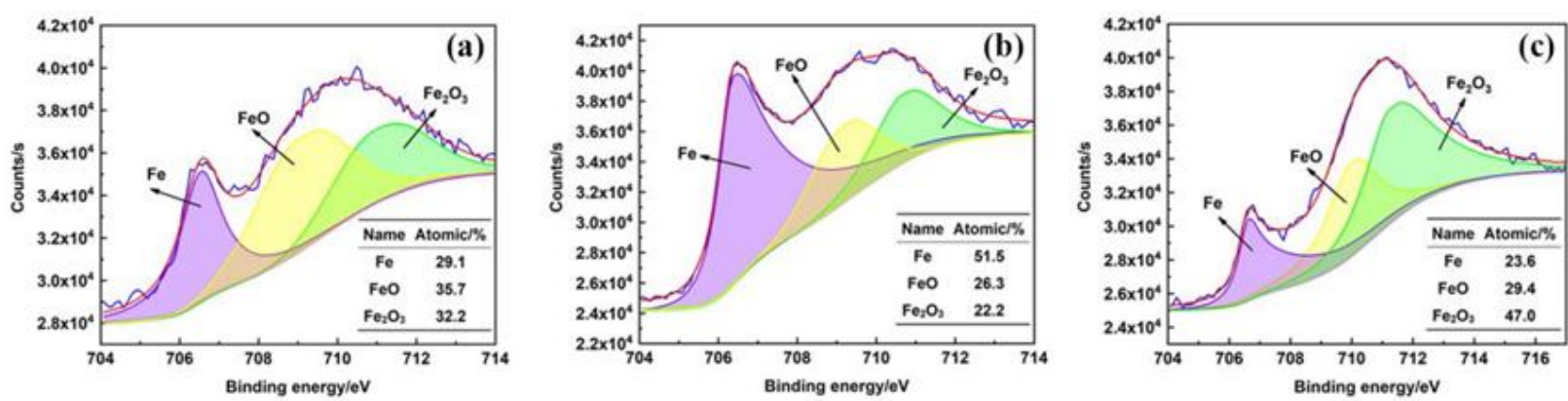

Figure 11. Fe2p peak fitting of 2205 DSS cladding layer under different current. (a) 90 A; (b) 100 A; (c) $110 \mathrm{~A}$
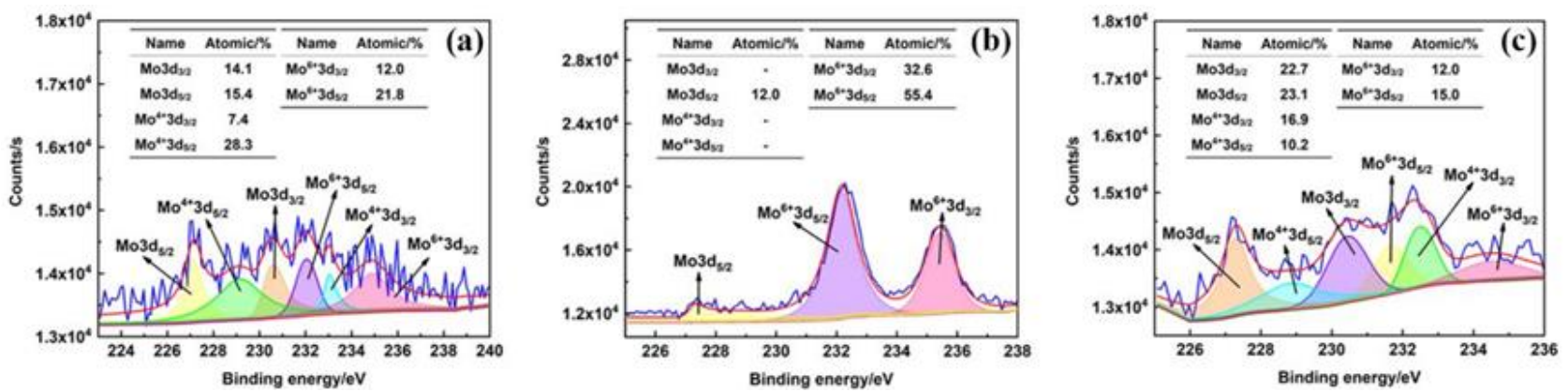

Figure 12. Mo2p peak fitting of 2205 DSS cladding layer under different current. (a) 90 A; (b) 100 A; (c) $110 \mathrm{~A}$.
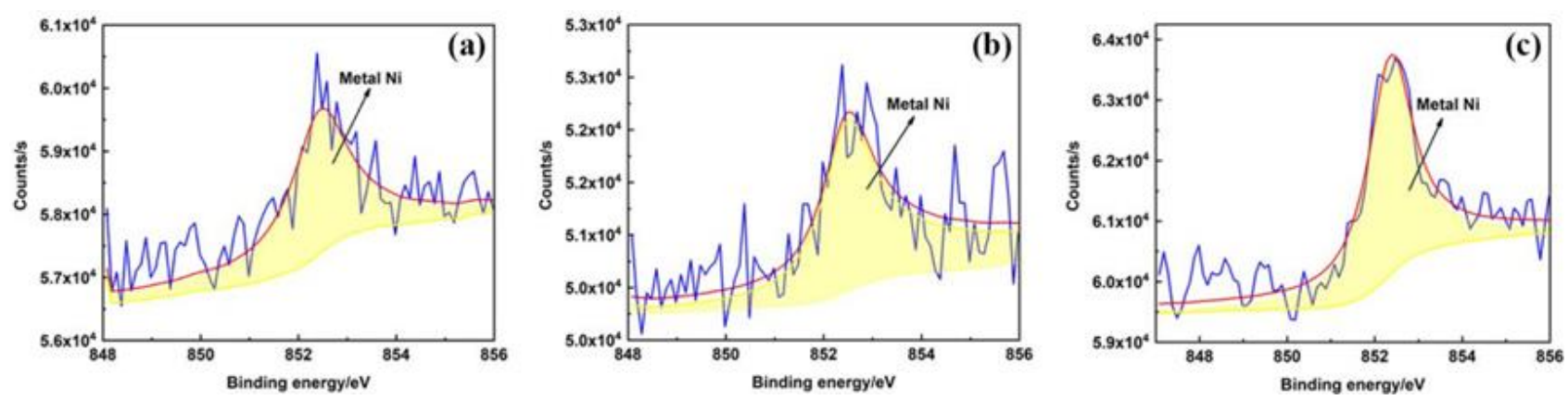

Figure 13. Ni2p peak fitting of 2205 DSS cladding layer under different current. (a) 90 A; (b) 100 A; (c) $110 \mathrm{~A}$. 

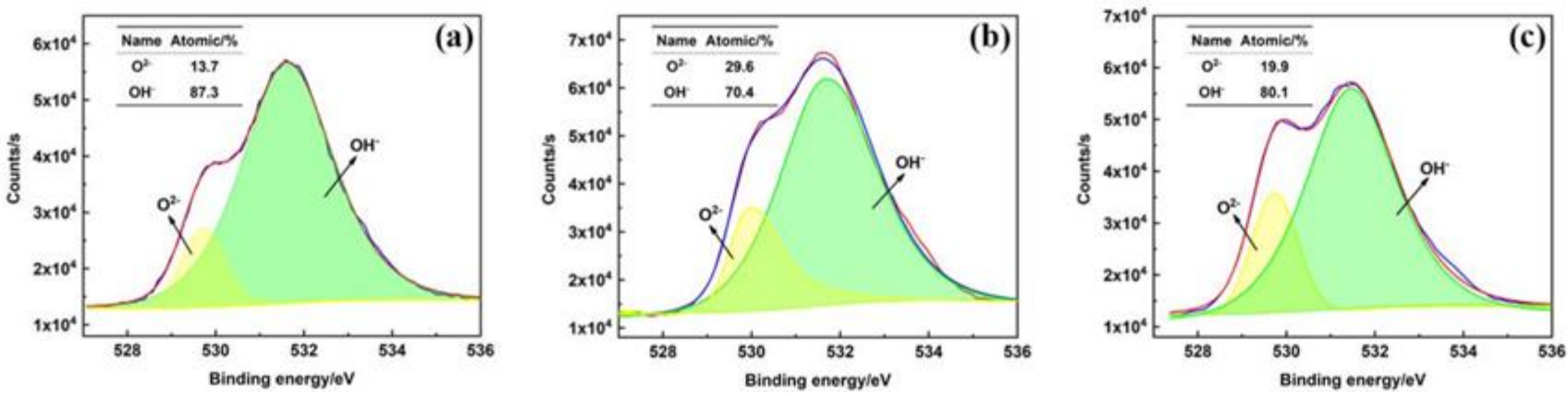

Figure 14. O2p peak fitting of 2205 DSS cladding layer under different current. (a) 90 A; (b) 100 A; (c) $110 \mathrm{~A}$.

Figure 11 presents the iron profile performs three primary peaks: $\mathrm{Fe}(706.7 \mathrm{eV}), \mathrm{FeO}$ $(709.3 \mathrm{eV})$ and $\mathrm{Fe}_{2} \mathrm{O}_{3}(711.3 \mathrm{eV})$, which indicates $\mathrm{Fe}^{2+}$ and $\mathrm{Fe}^{3+}$ are the main types of iron oxides in the passive film. The proportion of metal Fe was up to the maximum of $51.5 \%$ when the current was $100 \mathrm{~A}$.

Figure 12 shows that the molybdenum profile peaks of metals $\mathrm{Mo}, \mathrm{Mo}^{4+}$ and $\mathrm{Mo}^{6+}$ could be detected in the passive film. Obviously, the metal Mo can be clearly observed in the passive film, due to Mo being not easily oxidized such as Fe and $\mathrm{Cr}$ [29]. Mo can enhance the compactness of passive film so as to improve the corrosion resistance of cladding layer. Meanwhile, some literature has proved that the Mo element in passive film of 2205 DSS can prevent the adsorption of $\mathrm{Cl}^{-}$to the surface of passive film and reduce the migration rate of $\mathrm{Cl}^{-}$through the passive film [30]. As the current was $100 \mathrm{~A}, \mathrm{Mo}^{6+}$ was the primary constituent of passive film.

Figure 13 shows that the nickel profile performs one characteristic peak of metal $\mathrm{Ni}(852.8 \mathrm{eV})$. The Ni element, which is an austenite forming element, can increase the self-corrosion potential to enhance the corrosion resistance of steel [31].

Figure 14 shows the spectra of the passive film formed in the O2p region. Oxygen species, $\mathrm{O}^{2-}$ and $\mathrm{OH}^{-}$in passive film, play a role of connecting metal ions. O2p spectra are split into $\mathrm{O}^{2-}(530.2 \mathrm{eV})$ and $\mathrm{OH}^{-}(531.8 \mathrm{eV})$. It can be seen that $\mathrm{OH}^{-}$and $\mathrm{O}^{2-}$ are the primary constituents of passive film, $\mathrm{OH}^{-}$corresponds to the formation of $\mathrm{M}_{\mathrm{x}}(\mathrm{OH})_{\mathrm{y}}(\mathrm{M}-$ Metal), and $\mathrm{O}^{2-}$ corresponds to the forming of $\mathrm{M}_{\mathrm{x}} \mathrm{O}_{\mathrm{y}}$.

When the cladding layer sample was immersed in $3.5 \% \mathrm{NaCl}$ solution, a corrosion mirocell was formed on the surface of the sample. The depolarization reaction of oxygen took place at the cathode of micro cell, as shown in formula (1). In contrast, the dissolution reaction of the metal matrix $(\mathrm{Fe}, \mathrm{Cr})$ occurred at the anode of micro cell, as shown in formula (2 9) [32,33]. Based on EET theory, the smaller the covalent electrons number of the strongest bond, the easier it is to form a new phase [32]. Many previous literatures has proved that the covalent electron number $\mathrm{n}_{\mathrm{A}}$ of the strongest bond of $\mathrm{Cr}_{2} \mathrm{O}_{3}$ is 0.95284 , while $\mathrm{n}_{\mathrm{A}}$ of $\mathrm{Fe}_{2} \mathrm{O}_{3}$ is 1.12898. Obviously, the $\mathrm{n}_{\mathrm{A}}$ of $\mathrm{Cr}_{2} \mathrm{O}_{3}$ is smaller. Therefore, $\mathrm{OH}^{-}$in the corrosion solution is adsorbed to the surface of cladding layer, it preferentially reacts with $\mathrm{Cr}$ to form $\mathrm{Cr}_{2} \mathrm{O}_{3}$, and then it interacts with $\mathrm{Fe}$ to form $\mathrm{Fe}_{2} \mathrm{O}_{3}$ and $\mathrm{FeO}$.

Cathode reaction:

$$
\mathrm{O}_{2}+\mathrm{H}_{2} \mathrm{O}+4 e \rightarrow 4 \mathrm{OH}^{-}
$$

Anode reaction for $\mathrm{Cr}$ :

$$
\begin{gathered}
\mathrm{Cr}+\mathrm{H}_{2} \mathrm{O} \rightarrow \mathrm{Cr}(\mathrm{OH})_{a d s}+\mathrm{H}^{+}+2 e^{-} \\
\mathrm{Cr}(\mathrm{OH})_{a d s}+\mathrm{OH}^{-} \rightarrow \mathrm{Cr}(\mathrm{OH})^{2+}+2 e^{-} \\
\mathrm{Cr}(\mathrm{OH})^{2+}+2 \mathrm{OH}^{-} \rightarrow \mathrm{Cr}(\mathrm{OH})_{3} \\
2 \mathrm{Cr}(\mathrm{OH})_{3} \rightarrow \mathrm{Cr}_{2} \mathrm{O}_{3}+3 \mathrm{H}_{2} \mathrm{O}
\end{gathered}
$$


Anode reaction for Fe:

$$
\begin{gathered}
\mathrm{Fe}+\mathrm{H}_{2} \mathrm{O} \rightarrow \mathrm{Fe}(\mathrm{OH})_{a d s}+\mathrm{H}^{+}+e^{-} \\
\mathrm{Fe}(\mathrm{OH})_{a d s}+\mathrm{OH}^{-} \rightarrow \mathrm{Fe}(\mathrm{OH})_{2}+e^{-} \\
\mathrm{Fe}(\mathrm{OH})_{2}+\mathrm{OH}^{-} \rightarrow \mathrm{Fe}(\mathrm{OH})_{3}+e^{-} \\
2 \mathrm{Fe}(\mathrm{OH})_{3}+2 \mathrm{OH}^{-} \rightarrow \mathrm{Fe}_{2} \mathrm{O}_{3}+\mathrm{FeO}+4 \mathrm{H}_{2} \mathrm{O}+2 e^{-}
\end{gathered}
$$

After the corrosion reaction, many active sites formed on the surface of the passive film, which resulted in the instability of oxide film [34]. However, $\mathrm{Mo}^{6+}$ formed the hydroxide of Mo at these active sites, which helped to create a stable passive film. Some literature shows that the presence of $\mathrm{Mo}^{6+}$ promotes the formation of $\mathrm{Cr}_{2} \mathrm{O}_{3}[35,36]$. By comparison, different currents have no effect on the element composition of passive film. When the current was $100 \mathrm{~A}$, chromium enrichment occurred in the oxide film protective layer, especially the proportion of $\mathrm{Cr}_{2} \mathrm{O}_{3}$ increased significantly. Meanwhile, the proportion of $\mathrm{Mo}^{6+}$ in the passive film was up to the maximum. $\mathrm{Cr}_{2} \mathrm{O}_{3}$ plays an essential role in the corrosion resistance of passive film [37]. Therefore, the optimal process parameters of 2205 DSS cladding layer obtained by plasma arc cladding technology are wire feeding speed of $29 \mathrm{~mm} / \mathrm{s}$, welding speed of $6 \mathrm{~mm} / \mathrm{s}$, ion gas flow of $1 \mathrm{~L} / \mathrm{min}$, gas flow of $20 \mathrm{~L} / \mathrm{min}$, Nozzle height of $10 \mathrm{~mm}$ and the current of $100 \mathrm{~A}$.

\section{Conclusions}

The 2205 DSS cladding layer was prepared on the surface of a low carbon steel by plasma arc cladding technology. The effects of different current on the macro morphology, austenite/ferrite mass ratio and corrosion resistance of the cladding layer were studied. The main conclusions were drawn as followings:

(1) The current increased from $80 \mathrm{~A}$ to $120 \mathrm{~A}$, the dilution ratio of cladding layer increased, and its macro morphology varied. When the current was $100 \mathrm{~A}$, the forming of cladding layer was continuous, complete and fine with the dilution ratio of $11.43 \%$.

(2) Regardless of the current, the microstructure of cladding layer was composed of austenite and ferrite. The mass ratio of austenite to ferrite in the microstructure increased with the increase of current. It was up to the optimum of 1.207 with the current of $100 \mathrm{~A}$.

(3) When the current was $100 \mathrm{~A}$, the self-corrosion potential of cladding layer was the maximum while the corrosion current density was the minimum, and the corrosion resistance of cladding layer was the optimum. The main reason was the existence of $\mathrm{Mo}^{6+}$ in the passive film, which stabilized the passive film and promoted the formation of $\mathrm{Cr}_{2} \mathrm{O}_{3}$.

Author Contributions: Conceptualization: J.P., W.L. and M.W.; methodology: P.X. and J.P.; formal analysis: J.P. and P.X.; resources: Y.S. and J.S.; data curation: P.X. and J.S.; writing-original draft preparation: J.P. and P.X.; writing-review and editing: J.P. and W.L.; writing-manuscript finalization: J.P.; W.L. and M.W. supervision: J.P. and W.L.; project administration: W.L. and Y.S.; funding acquisition: Y.S. and J.S. All authors have read and agreed to the published version of the manuscript.

Funding: This research was supported by State Key Laboratory of Advanced Brazing Filler Metals and Technology, the Natural Science Foundation of Jiangsu Province (Grant No. BK20191458), the Technology and Innovation Program for Undergraduates of Jiangsu University of Science and Technology, the Research and Practice innovation plan for Postgraduates in Jiangsu Province(No. SJCX 20-1457), and the open research foundation of the State Key Laboratory of Advanced Welding and Joining (No. AWJ-21M15).

Institutional Review Board Statement: Not applicable.

Informed Consent Statement: Not applicable.

Data Availability Statement: Not applicable. 
Conflicts of Interest: The authors declare no conflict of interest. The funder had no role in the design of the study; in the collection, analyses, or interpretation of data; in the writing of the manuscript; or in the decision to publish the results.

\section{References}

1. Fu, H.W.; Dönges, B.; Krupp, U.; Pietsch, U.; Fritzen, C.-P.; Yun, X.B.; Christ, H.-J. Evolution of the residual stresses of types I, II, and III of duplex stainless steel during cyclic loading in high and very high cycle fatigue regimes. Int. J. Fatigue 2020, 142,105972 [CrossRef]

2. Yuya, H.; Kobayashi, R.; Otomo, K.; Yabuuchi, K.; Komura, A. Microstructure and mechanical properties of HAZ of RPVS clad with duplex stainless steel. J. Nucl. Mater. 2021, 545, 152756. [CrossRef]

3. Zhang, Z.Q.; Jing, H.Y.; Xu, L.Y.; Zhang, T.G.; Xu, Y.T. Research progress on microstructure and properties of welded joint of ferrite/austenite duplex stainless steel. Trans. Mater. Heat Treat. 2020, 41, 13-27.

4. Rajesh-Kannan, A.; Siva-Shanmugam, N.; Rajkumar, V.; Vishnukumar, M. Insight into the microstructural features and corrosion properties of wire arc additive manufactured super duplex stainless steel (ER2594). Mater. Lett. 2020, 270, 127680. [CrossRef]

5. Dong, C.F.; Luo, H.; Xiao, K.; Sun, T.; Liu, Q.; Li, X.G. Effect of temperature and $\mathrm{Cl}^{-}$concentration on pitting of 2205 duplex stainless steel. J. Wuhan Univ. Technol. Mater. Sci. Ed. 2011, 26, 641-647. [CrossRef]

6. Khattak, M.A.; Zaman, S.; Kazi, S.; Ahmed, H.; Habib, H.M.; Ali, H.M.; Tamin, M.N. Failure investigation of welded 430 stainless steel plates for conveyor belts. Eng. Fail. Anal. 2020, 116, 104754. [CrossRef]

7. $\mathrm{Pu}, \mathrm{J} . ; \mathrm{Li}, \mathrm{Z} . P . ; \mathrm{Hu}, \mathrm{Q} . X . ;$ Wang, Y.X. Effect of heat treatment on microstructure and wear resistance of high manganese steel surfacing layer. Int. J. Mod. Phys. B 2019, 33, 1940035. [CrossRef]

8. Wu, L.; Pu, J.; Wu, M.F.; Long, W.M.; Zhong, S.J.; Hu, Q.X.; Lan, Y. Effects of different tungsten carbide contents on microstructure and properties of Ni-based tungsten carbide cladding layer by plasma arc cladding technology. Mater. Rep. 2021, 35, 16111-16114, 16119.

9. Jin, M.; He, D.Y.; Wang, Z.J.; Zhou, Z.; Wang, G.H.; Li, X.X. Microstructure and properties of laser cladded 2205 dual-phase stainless steel/TiC composite coatings. Laser. Optoelectron. P 2018, 055, 285-290.

10. Pu, J.; Rao, J.W.; Shen, Y.F.; Liu, C.; Zhang, L.; Wang, Y.X. Effect of Ti element on the microstructure and properties of high chromium surfacing layer. Int. J. Mod. Phys. B 2020, 34, 2040028. [CrossRef]

11. Chen, L.; Richter, B.; Zhang, X.Z.; Ren, X.D.; Frank, E.; Pfefferkorn, B. Modification of surface characteristics and electrochemical corrosion behavior of laser powder bed fused stainless-steel 316L after laser polishing. Addit. Manuf. 2020, 32, 101013. [CrossRef]

12. Liu, S.; Fang, W.P.; Yi, Y.Y.; Deng, Y.L. Study on microstructure and properties of flux cored twin-wire CMT welded joint of 2205 duplex stainless steel. H. Work. Technol. 2020, 49, 16-19, 24.

13. Liu, Y.; Bao, Y.F.; Song, Q.N.; Jiang, Y.F. Influence of sensitization on pitting corrosion in surfacing layer of 2209 duplex stainless steel. Trans. China Weld. Inst. 2020, 41, 33-38, 98-99.

14. Brunner-Schwer, C.; Petrat, T.; Graf, B.; Rethmeier, M. Highspeed-plasma-laser-cladding of thin wear resistance coatings: A process approach as a hybrid metal deposition-technology. Vacuum 2019, 166, 123-126. [CrossRef]

15. Ding, H.; Dai, J.W.; Dai, T.; Sun, Y.W.; Lu, T.; Jia, X.J.; Huang, D.S. Effect of preheating/post-isothermal treatment temperature on microstructures and properties of cladding on U75V rail prepared by plasma cladding method. Surf. Coat. Technol. 2020, 399, 126122. [CrossRef]

16. Huang, J.K.; Liu, S.; Yu, S.R.; An, L.; Yu, X.Q.; Fan, D.; Yang, F.Q. Cladding Inconel 625 on cast iron via bypass coupling micro-plasma arc welding. J. Manuf. Process. 2020, 56, 106-115. [CrossRef]

17. Cui, S.; Pang, S.; Pang, D.; Zhang, Z. Influence of Welding Speeds on the Morphology, Mechanical Properties, and Microstructure of 2205 DSS Welded Joint by K-TIG Welding. Materials 2021, 14, 3426. [CrossRef] [PubMed]

18. Rodriguez, B.R.; Miranda, A.; Gonzalez, D. Maintenance of the Austenite/Ferrite Ratio Balance in GTAW DSS Joints Through Process Parameters Optimization. Materials 2020, 13, 780. [CrossRef]

19. Hany, S.; Asiful, H.S.; Jabair, A.M.; Tauriq, U. Ameliorative Corrosion Resistance and Microstructure Characterization of 2205 Duplex Stainless Steel by Regulating the Parameters of Pulsed Nd:YAG Laser Beam Welding. Metals 2021, 11, 1206.

20. Syed, W.U.H.; Pinkerton, A.J.; Li, L. A comparative study of wire feeding and powder feeding in direct diode laser deposition for rapid prototyping. Appl. Surf. Sci. 2005, 247, 268-276. [CrossRef]

21. Lin, C.M. Parameter optimization of laser cladding process and resulting microstructure for the repair of tenon on steam turbine blade. Vacuum 2015, 115, 117-123. [CrossRef]

22. Wang, H.; Woo, W.; Kim, D.-K.; Em, V.; Lee, S.Y. Effect of chemical dilution and the number of weld layers on residual stresses in a multi-pass low-transformation-temperature weld. Mater. Des. 2018, 160, 384-394. [CrossRef]

23. Hemmati, I.; Ocelik, V.; De-Hosson, J.T.M. Dilution effects in laser cladding of Ni-Cr-B-Si-C hardfacing alloys. Mater. Lett. 2012, 84, 69-72. [CrossRef]

24. Kang, D.H.; Lee, H.W. Study of the correlation between pitting corrosion and the component ratio of the dual phase in duplex stainless steel welds. Corros. Sci. 2013, 74, 396-407. [CrossRef]

25. Abreu, C.M.; Cristóbal, M.J.; Losada, R.; Nóvoa, X.R.; Pena, G.; Pérez, M.C. The effect of Ni in the electrochemical properties of oxide layers grown on stainless steels. Electrochim. Acta 2006, 51, 2991-3000. [CrossRef] 
26. Guiñón-Pina, V.; Igual-Muñoz, A.; García-Antón, J. Influence of pH on the electrochemical behaviour of a duplex stainless steel in highly concentrated LiBr solutions. Corros. Sci. 2011, 53, 575-581. [CrossRef]

27. Jin, T.Y.; Cheng, Y.F. In situ characterization by localized electrochemical impedance spectroscopy of the electrochemical activity of microscopic inclusions in an X100 steel. Corros. Sci. 2011, 53, 850-853. [CrossRef]

28. Boissy, C.; Alemany-Dumont, C.; Normand, B. EIS evaluation of steady-state characteristic of 316L stainless steel passive film grown in acidic solution. Electrochem. Commun. 2013, 26, 10-12. [CrossRef]

29. Montemor, M.F.; Simões, A.M.P.; Ferreira, M.G.S.; Belo, M.D.C. The role of Mo in the chemical composition and semiconductive behaviour of oxide films formed on stainless steels. Corros. Sci. 1999, 41, 17-34. [CrossRef]

30. Zhang, B.; Wei, X.X.; Wu, B.; Wang, J.; Shao, X.H.; Yang, L.X.; Zheng, S.J.; Zhou, Y.T.; Jin, Q.Q.; Qguzie, E.E.; et al. Chloride attack on the passive film of duplex alloy. Corros. Sci. 2019, 154, 123-128. [CrossRef]

31. Potgieter, J.H.; Olubambi, P.A.; Cornish, L.; Machio, C.N.; Sherif, E.-S.M. Influence of nickel additions on the corrosion behaviour of low nitrogen $22 \% \mathrm{Cr}$ series duplex stainless steels. Corros. Sci. 2008, 50, 2572-2579. [CrossRef]

32. Wang, Y.; Li, C.F.; Lin, Y.H. Electronic theoretical study of the influence of $\mathrm{Cr}$ on corrosion resistance of Fe-Cr alloy. Acta Metall. Sin. 2017, 53, 622-630.

33. Li, F.; Wu, Y.S.; Yang, D.J.; Zhang, W.Q. The possive film and pitting propagation models of Fe-Cr alloy. J. Beijing Univ. Iron Steel Technol. 1986, 1, 125-134.

34. Cheng, X.Q.; Wang, Y.; Li, X.G.; Dong, C.F. Interaction between austein-ferrite phases on passive performance of 2205 duplex stainless steel. J. Mater. Sci. Technol. 2018, 34, 2140-2148. [CrossRef]

35. Betova, I.; Bojinov, M.; Karastoyanov, V.; Kinnunen, P.; Saario, T. Estimation of kinetic and transport parameters by quantitative evaluation of EIS and XPS data. Electrochim. Acta 2010, 55, 6163-6173. [CrossRef]

36. Pardo, A.; Merino, M.C.; Coy, A.E.; Viejo, F.; Arrabal, R.; Matykina, E. Pitting corrosion behaviour of austenitic stainless steels-combining effects of Mn and Mo additions. Corros. Sci. 2008, 50, 1796-1806. [CrossRef]

37. Abreu, C.M.; Cristóbal, M.J.; Losada, R.; Nóvoa, X.R.; Pena, G.; Pérez, M.C. High frequency impedance spectroscopy study of passive films formed on AISI 316 stainless steel in alkaline medium. J. Electroanal. Chem. 2004, 572, 335-345. [CrossRef] 